\title{
Anna Sakowicz*
}

Uniwersytet w Białymstoku

https://orcid.org/0000-0001-5685-6076

\section{Вобраз роднага ў лірычнай прозе Юркі Геніюша}

Рэзюме: У артыкуле аналізуецца лірычная проза Жменька слоў крылатых Юркі Геніюша (1935-1985), члена Беларускага літаратурнага аб'яднання “Белавежа” у Польшчы. Родны дом, маці, родная мова, беларуская культура гэта “магічная” парадыгма адзінага сына вядомай беларускай паэткі Ларысы Геніюш, якая за любоў да Беларусі заплаціла самую высокую цану для жанчыны - сваім мацярынствам.

Лірыка паэта насычана сірочым болем асобы ў раннім узросце адарванай ад бацькоў, ад Радзімы. Юрка Геніюш як і маці быў верным роднай мове, беларускай культуры і традыцыі. Мастак перасцерагае беларусаў Польшчы перад стратай нацыянальнай тоеснасці.

Ключавыя словы: лірычная проза, родная мова, беларуская культура, маці, родны дом.

Anna Sakowicz - dr, literaturoznawca, białorutenistka, adiunkt w Zakładzie Białorutenistyki i Literatur Wschodniosłowiańskich na Wydziale Filologicznym Uniwersytetu w Białymstoku. Autorka monografii: Belaruskaâ litaratura Pol'ščy. Stylìstyčna-žanravyâ asablìvascì prozy"belavežcaǔ (Białystok 2012). 


\section{A native picture in the lyrical prose of Jerzy Geniusz}

Summary: The article analyses lyrical prose $A$ handful of winged words by Jerzy Geniusz (a member of Belarusian Literary Association ‘Białowieza' in Poland). Family home, mother, mother tongue, Belarusian culture are a 'magic' paradigm of the only son of a steadfast Belarusian poet Łarysa Geniusz, who for the love of Belarus paid the highest price for a woman which is maternity.

Lyric poetry of the son of dedicated Belarusian patriots, prisoners of the Soviet labor camps, are filled with the pain of orphaned adolescence in exile. Jerzy Geniusz in the legacy of his mother-poet assumes the mission of defending his mother tongue, the mission of preserving Belarusian culture and traditions. The artist warns Polish Belarusians against the loss of their native culture, mother tongue.

Key words: lyric prose, mother tongue, Belarusian culture, mother, family home.

\section{Obraz ojczysty w prozie lirycznej Jerzego Geniusza}

Streszczenie: Artykuł poświęcony jest analizie prozy lirycznej Garstka słów skrzydlatych Jerzego Geniusza, członka Białoruskiego Stowarzyszenia Literackiego „Białowieża” w Polsce. Dom rodzinny, matka, język ojczysty, kultura białoruska to „magiczny” paradygmat jedynego syna niezłomnej poetki białoruskiej Łarysy Geniusz, która za miłość do Białorusi zapłaciła najwyższą dla kobiety cenę, jaką jest macierzyństwo.

Liryka poety nasycona jest bólem sieroty w dzieciństwie oderwanego od rodziców, Ojczyzny. Jerzy Geniusz, podobnie jak matka, był wierny mowie ojczystej, kulturze i tradycji białoruskiej. Artysta ostrzega Białorusinów z Polski przed stratą tożsamości narodowej.

Słowa-klucze: proza liryczna, język ojczysty, kultura białoruska, matka, dom rodzinny. 
Творчасць Юркі Геніюша (1935-1985), выдатнай асабовасці першага пакалення творцаў Беларускага Літаратурнага Аб’яднання ў Польшчы “Белавежа", якое угрунтавана на польска-беларускім памежжы ${ }^{1}$, сына слыннай беларускай паэткі Ларысы Геніюш², прасякнута асаблівай любоўю да роднага, да беларускага слова.

Юрка Геніюш (псеўданім Ларс) дэбютаваў 20 кастрычніка 1963 года у “Ніве” апавяданнем Прыкметы. Пазней друкаваў свае творы на старонках той жа “Нівы”, у літаратурных альманахах “Белавежы” ці ў “Беларус-

1 Катэгорыя “памежжа” ўбірае ў сябе прастору, на якой пражывае і рэалізуецца акрэслены тып дзвюх або больш этнічна-культурных групаў. На маю думку найбольш дакладны тэрмін “памежжа” сфарміраваны ў кнізе: Kulturowo-językowe dziedzictwo Podlasia, tom I, Opis socjolingwistyczny regionu na tle uwarunkowań historycznych, opracowanie tomu Nina Barszczewska i Mikołaj Timoszuk, Warszawa 2016, s. 21. Pogranicze - teren znajdujący się między dwoma lub kilkoma centrami - jest ściśle związane z pojęciem tożsamości. Powstaje, gdy granice tych centrów nakładają się na siebie i tworzą obszar. Wówczas mieszkaniec pogranicza może należeć do każdego z owych centrów. Pogranicze jest obszarem specyficznym, bardzo różnorodnym, bez określonych ram. Teren ten jest znacznie bogatszy od obszaru jednolitego. Istotny wpływ ma tu między innymi istniejąca wielojęzyczność czy wielokulturowość. Mieszkańcy pogranicza uczą się odbioru innej, jednak już nie obcej kultury, zachowań czy zwyczajów.

2 Ларыса Геніюш (1910-1983), паэтка, дэбютавала ў 1940 годзе вершам Беларуска на старонках эміграцыйнай газеты "Раніца". 3'яўляецца аўтаркай наступных паэтычных зборнікаў: Ад родных ніў (1942), Невадам з Нёмана (1967), На чабары настоена (1982), а таксама кніг для дзяцей: Казкі для Міхаські (1972), Добрай раніцы, Алесь (1976). У 1990 годзе пабачыў свет апошні зборнік вершаў Бель сон. У часопісе "Спадчына" надрукавана паэма Маёй бабусі (1989). Год пазней у часопісе "Маладаосць" (№ 1-6, 1990) друкавалася ацэнзураваная лагерная аповесць, рукапіс якой паэтка перадала на перахаванне Міхасю Чарняўскаму. Наколькі твор не меў загалоўка, то сакратар газеты Янка Сіпакоў вырашыў назваць Споведзь. У 1993 годзе ўспаміны Л. Геніюш выйшлі ў Міньску ў форме кнігі.

У 1937 годзе Ларыса з сынам пераехала да мужа ў чэшскую Прагу, дзе ён у Карлавым універсітеце вучыўся на медыцынскім факультэце. 3 той прычыны, што паэтэса супрацоўнічала з антысавецкай беларускай эміграцыяй, з урадам БНР (узначальваў яго Васіль Захарка), то 5 сакавіка 1948 года агенты савецкай спецслужбы арыштоўваюць Ларысу Геніюш разам з мужам Янкам, пазбаўляюць іх чэхаславацкага грамадзянства, і ў жніўні вывозяць у Мінск. Там асабіста яе дапытваў тагачасны міністр Міністэрства Дзяржаўнай Бяспекі (МГБ) БССР Лаўрэнцій Цанава, патрабуючы ад паэтэсы звароту архіва БНР. 7 лютага 1949 года Вярхоўны суд БССР прыгаварыў Ларысу і Янку Геніюшаў на 25 гадоў папраўча-працоўных лагераў. Пакаранне яны адбывалі далёка на Поўначы былога СССР у асобных лагерах (Ларыса на Інце і ў Абезі). Вярнуліся Геніюшы у Зэльву ў 1956 годзе. У родным мястэчку яны жылі да самай смерці, так і не прымаючы савецкага гарамадзянства. 
кіх календарах". Першым кніжным выданнем была кніга паэзіі ў перакладзе на польскую мову Яна Леаньчука Na poczatku byto stowo 3 . Чарговыя выданні з'явіліся пасля ягонай заўчаснай смерці. У 1992 годзе пабачыла свет кніга вершаў Юркі Геніюша Да свету, якая была ўключана ў зборнік лірычнай прозы Маиі i cынt 4 (выйшла пад адной вокладкай з вершамі маці). Год пазней пабачыла свет кніга прозы 3 маёй званіцы 5 .

Дваццаць гадоў пазней з'явілася кніга Смыком па сэриы саблівае поўнае выданне ўсяго творчага дасягнення Юркі Геніюша, тое, што ён паспеў надрукаваць, сярод чаго аказаліся цяпер у адным выданні аказіянальныя газетныя допісы, фельетоны і Жменька слоў крыла$m b l x^{7}$. Назва гэтай кнігі адпавядае якраз асаблівасці той “жменьцы слоў крылатых", той лірычнай прозы, якая сваёй формай і зместам адпавядае жанру “міні-проза”, „якая сёння можа быць не толькі лірычнай, але і драматычнай, і эсэістычнай, і філасофскай, і гумарыстычнай”. Творчая індывідуальнасць Юркі Геніюша, які выкарыстоўвае іншасказанне, вобразна-сімвалічную абагуленасць, дае падставы ўпісаць яе ў рамкі лірыкафіласафічнай прозы.

Факт, што мастак слова дэбютаваў і разгарнуўся ў сваёй творчасці на Беласточчыне, у прасторы польска-беларускага памежжа, на якой праблемы асабліва засяроджаны на ўсведамленні нацыянальнай прыналежнасці, сустрэчы з “іншым”, дазваляе знаходзіць асацыяцыі з разважаннямі Міхаіла Бахціна9 аб “філасофіі дыялогу”. Значнасць яго думкі асабліва ў час глабалізацыі, якая імкнецца прынесці прысуд нацыянальнаму, падкрсэлівае Адам Арлоўскі: "Na pograniczu etnicznym, religijnym, świato-

3 J. Leończuk, Na początku było słowo, Białystok 1981.

4 Маці і сын, Ларыса Геніюш: Сэрйа, Юрка Геніюш: Да свету, Беласток 1992.

5 Ю. Геніюш, 3 маёй званіи̧ь, Беласток 1993.

6 Ю. Геніюш, Смыком па сэриы, Беласток 2013.

7 Метафарычны загаловак твораў быў нададзены не аўтарам, а складальніцай кнігі - Мірай Лукшай.

8 Г. Тычка, Аўтарская канцңэпџыя чалавека і свету ў мініяцуюрах Сакрата Яновіча і Яна Чьлкіна, [w:] Той жа, Наџьиянальнае. Індывідуальнае. Агульначалавечае, Беласток 2015, c. 82.

9 M. Bachtin, Koncepcja nauki o literaturze, [w:] Bachtin: dialog-język-literatura, pod red. E. Czaplejewicza i E. Kasperskiego, Warszawa 1983. 
poglądowym, gdzie ma miejsce wspólna egzystencja zróżnicowanych grup społecznych, poszczególne jednostki mają okazję do głębszego przeżywania swojego społeczeństwa"10.

Зварот пісьменнікаў XX і XXI стагоддзяў да дыялогу прыкмячае Iрына Гоўзіч. На думку даследчыцы сучасная літаратура:

- гэта ўжо не толькі апісанне рэчаіснасці, прыроды і падзей, прапушчанае праз стан чалавечай душы, гэта таксама і шматгранныя дыялогі - дыялог з часам, аднаго аўтара з другімі аўтарамі, аўтара з чытачом, з самім сабой, 3 “цэлым народам", з душой сваёй і з Богам. Думка ў падобных творах не ляжыць на паверхні, а вынікае з глыбіні душэўнага вопыту, гэта пэўным чынам інтанаванае выказванне, якое залежыць ад прадмета ўвагі і адрасата ${ }^{11}$.

Своеасаблівым каталізатарам дыялогавасці з'яўляецца большасць тэкстаў Юркі Геніюша са Жменькі слоў крылатых, дакладна іх - трыццаць два. Калі ўзяць пад увагу загаловак артыкула, прадметам аналізу з'яўляецца адзінаццаць твораў, у якіх праз любоў да слова аўтар ускосна выяўляе любоў да радзімы, народа, ягонай гісторыі, культуры, бо ўсё “адзета" ў тое ж сваё роднае слова.

На вялікі жаль, мастак слова не так шмат пакінуў па сабе літаратурных твораў. Знакавая фігура ў літаратурна-навуковым асяроддзі, Ян Чыквін тлумачыць гэта тым, што: “Не знаючы сваёй гадзіны, здаецца, не прадчуваючы благога, Юрка Геніюш не спяшаўся, пісаў адносна мала, мяркую, што адкладваў літаратурны занятак напасля" ${ }^{2}$. Да напісанага ён не прывязваў асаблівай увагі, не правіў тэкстаў і не клапаціўся пра ix друк. Несумненна, важкім фактарам была знясільваючая праца педыятра, якая “паглынала” шмат энергіi. Пасля прафесійных абавязкаў, Геніюш

10 A. Orłowski, Fascynacje pograniczem $w$ dwudziestowiecznej myśli filozoficznej $i$ antropologicznej-Bachtin, Todorov, Buber, Lèvinas, „Pogranicze. Polish Borderlands Studies”, t. 4 , nr 1, s. 10 .

11 І. Гоўзіч, Лірыка-філасофская проза Юркі Геніюша, “Тэрмапілы” 2008, № 12, c. 295 .

12 Я. Чыквін, Партрэт з памяиі, [w:] Таго ж, Далёкія і блізкія. Беларускія пісьменнікі замежжа, Беласток 1997, с. 117. 
меў права не мець часу і сілы, каб творча працаваць над нечым даўжэйшым, а вершы ягоныя, невялікія апавяданні, кароткая лірычная проза усё гэта пачатак нечага большага, нейкія фрагменты, нейкая абарванасць, нейкія намёкі на штосьці. “А можа стрымлівала ягоную творчасць тое, 3 чым не мог не лічыцца: ён жа быў сынам, як тады гаварылася, здраднікаў айчыны, ворагаў народа, бацькоў зведаўшых Поўнач"13.

Бясспрэчна, што велічыня і значнасць пісьменніка не залежыць ад лічбовай прадуктыўнасці. У гісторыі літаратуры, таксама беларускай, ёсць невялікія творы, сціплыя на першы выгляд кніжкі, якія выклікалі пералом, сталі знакавымі. Большасць часу Геніюш прысвяціў журналістыцы, пісаў у “Ніву” допісы, фельетоны, нейкія рэфлексіі. Вядома, публіцыстыка рэдка вытрымлівае выпрабаванне часам, але яна давала аўтару магчымасць падзарабіць. Аднак, з другога боку, на жаль, адбірала час, які можна было прысвяціць мастацкай творчасці, “засланяла яго” ад паэтычнага таленту.

Кніга жыцця пісьменніка закрылася назаўсёды ў 1985 годзе. На жаль, крытычная літаратура аб мастаку слова вельмі сціплая: два кароткія ўводныя словы да выданняу твораў Геніюша аўтарства: Сакрата Яновіча ${ }^{14}$ i Міры Лукшы ${ }^{15}$, адно пасляслоўе Яна Леаньчука ${ }^{16}$, i толькі два навуковыя артыкулы аўтарства: Яна Чыквіна ${ }^{17}$ і Ірыны Гоўзіч ${ }^{18}$. Асабіста знаёмай 3 Геніюшамі была гродзенская паэтэса Данута Бічэль ${ }^{19}$, якая падзялілася некаторымі інфармацыямі $з$ жыцця цэлай сям’і ў невялікім успаміне: Сям'я Геніюшаў - Ларыса і Янка, іх сын Юрка. Можна сцвердзіць, што

13 Тамсама, c. 118.

14 С. Яновіч, Прадмова, [w:] Маціі і сын, Ларыса Геніюш: Сэрияа, Юрка Геніюш: Да свету, Беласток 1992.

15 М. Лукша, Ой, мама, чаму я чорны..., [w:] Ю. Геніюш, Смыком па сэриь,, Беласток 2013, s. 5

16 J. Leończuk, Wersy poetyckie Jerzego Geniusza, [w:] Ю. Геніюш, Смыком па сэрйы, Беласток 2013, s. 223.

17 Я. Чыквін, Партрэт з памяиі, [w:] Таго ж, Далёкія і блізкія.. dz. суt., 117-122.

18 І. Гоўзіч, Лірыка-філасофская проза Юркі Геніюша, “Тэрмапілы” 2008, № 12, c. 294-298.

19 Д. Бічэль, Сям'я Геніюшаў - Ларыса і Янка, іх сын Юрка, [w:] Данута Бічэль, Выбраныя творы, Мінск 2016, с. 404- 414. 
наробак Геніюша чамусьці знаходзіцца па-за належнай увагай літаратуразнаўцаў. Чаму такое стаўленне да Юркі Геніюша? Здаецца, адказы у ягонай жыццёвай біяграфіi.

Лёсам было так наканавана, што двухгадовы Юрка Геніюш разам з маці мусіў пакінуць родную Зэльву і пераехаць у чэшскую Прагу, да бацькі, студэнта медыцынскага факультэта на Карлавым універсітэце. Супольнае жыццё ў Празе, мабыць, прайшло наогул бесклапотна. Затым навалілася на сям’ю трагедыя, бацькі арыштаваныя, аказаліся ў лагерах, а ён пакінуты на родзічаў. Юрка спярша жыў у матчыных сёстраў у Вроцлаве, каб урэшце патрапіць у Беласток, у асяроддзе беларускіх аўтахтонаў20.

Нашчадку “пачцівых ахвяраў штучнага ладу”21 пашчаслівілася працаваць у мястэчку Гарадок, што на польска-беларускім памежжы, якое спрадвеку насялялі беларусы, на вуліцах якога дамінавала беларуская мова, у якім панаваў беларускі дух. Сапраўды, мястэчка аказалася пісьменніку па душы, аб чым сведчаць апавяданні з нізкі У Гарадку $і$ наваколлі22.

Трэба адзначыць, што беларуская культура на Беласточчыне была заўсёды прысутнай, незалежна да якой дзяржавы належаў горад²3. Пацявр-

20 Нельга пагадзіцца са сцвярджэннем некаторых даследчыкаў, што беларусы Польшчы жывуць ў дыяспары. Такім паняццем ахвотна карыстаюцца замежныя даследчыкі - Арнольд Макмілін (Arnold MacMillin, Belarusian Literature of the Diaspora, Birmingham Slavonic Monographs 2002, No. 34,) як і беларускія - Вераніка Стральцова (Шлях да сябе. Сучасная аўтабіяграфічная проза як мастачкая сістэма, Мінск 2002, с. 106). Згодна са Слоўнікам іншамоўных слоў, выдадзеным у выдавецтве "Беларуская Энцыклапедыя”, слова дыяспара азначае сукупнасць прадстаўнікоў якога - н. народа, якія жывуць за межамі бацькаўшчыны ў новым раёне пасялення (А. М. Булыка, у 2 тамах, т. 1 А - Л, Мінск 1999, с. 459). Больш падрабязна гэты тэрмін растлумачаны ў польскім выданні слоўніка. Дыяспара гэта пражыванне, рассеянне адной нацыі сярод іншай, вернікаў адной рэлігіi сярод іншавераў (Stownik wyrazów obcych $P W N$, red. E. Sobol, Warszawa 2002, s. 235). Факт, што беларусы Беласточчыны нікуды не эмігравалі, а жывуць на зямлі продкаў, якіх яны з'яўляюцца спадкаемцамі не адбірае ім права на званне "аўтахтоны".

21 Я. Чыквін, Партрэт з памяиі, [w:] Таго ж, Далёкія і блізкія... dz. суt., с. 118.

22 Ю. Геніюш, У Гарадку і наваколлі, [у:] Таго ж, Смыком па сэриы, Беласток 2013, c. $7-35$.

23 Вальдэмар Смашч на пачатку 1990 года ва ўступным слове да кнігі Zblizenia. Portrety białostockich pisarzy, прызнаў, што ў Беластоку няма моцнага польскага літаратурнага асяроддзя, якое трывала адзначыла $б$ сваю прысутнасць у рэгіёне і дзяржаве. Літаратурны крытык пад уражаннем ад творчага плёну беларускіх мастакоў 
джэннем з'яўляецца выказванне паэта Майсея Сяднёва ${ }^{24}$, які ад кастрычніка 1943-га года да мая 1944-га года прабываў у Беластоку і назваў яго сваёй другой “Малой Айчынай”, на якой пазнаў сапраўдную Беларусь (падкр. - А.С.) і пачуў беларускую мову ${ }^{25}$.

Таленты Геніюш атрымаў генетычна і культурова ад бацькоў. У прафесійнай працы ішоў па слядах бацькі, закончыў Медыцынскую акадэмію ў Беластоку і стаў педыятрам. У творча-літаратурным - ад маці, паэтэсы, творцы 3 палітычна-нацыянальнай тэматыкай, падсветленай выразнымі сваімі сімпатыямі і антыпатыямі, што і вяло ў пасляваенныя гады непасрэдна да драмы.

“Крылатыя словы” Геніюша, як адзначае I. Гоўзіч, “насычаны медытатыўнасцю, што лучыцца $з$ глыбінным псіхалагізмам: любы аповед мае абавязковы выхад з лакальнага перажывання і асабістага пачуцця на паказ усеагульнага драматызму і універсальную трывогу [...]”26. Некаторыя творы 3 той “жменькі” часам адлюстроўваюць, на жаль, нізавую, гі-

слова: “Tworzą tu także pisarze białoruskojęzyczni, wydawani zarówno w kraju i za granicą. Sokrat Janowicz cieszy się uznaniem zarówno w Polsce, jak i na Wschodzie i Zachodzie (ma w swoim dorobku książki wydane w Mińsku i Londynie). Wszystkie te znaczące sukcesy pisarzy białostockich stanowią same w sobie literacki fenomen, gdyż niesłychanie rzadko zdarzają się owe „samorodki”, które niczym bryłki złotego kruszcu tkwią w piaskach pustyni. Zazwyczaj bywa tak, że bogate tradycje i lata aktywności artystycznej całego środowiska procentują wybitnym twórcą, który z kolei je dowartościowuje”. (...) I czego można zazdrościć temu środowisku, to właśnie ciągłości tradycji. Wszystkie ich inicjatywy są żywe są do dziś. (...) Kilku z członków grupy literackiej [„Białowieża” - dop. A.S.] należy dzisiaj do uznanych pisarzy, młodzi mają więc do kogo dołączać, kontynuować czy toczyć spory. Mniejszość ze swojej natury niejako jest bardziej interesująca, wzrasta więc zainteresowanie „naszymi Białorusinami”, a żywiołowa działalność Sokrata Janowicza, postaci niesłychanie kontrowersyjnej, sprawiła, że o kulturze i literaturze białoruskiej tworzonej na Białostocczyźnie głośno jest zarówno w kraju, jak i poza granicami. Zob. W. Smaszcz, Białostockie środowisko literackie, [w:] Zbliżenia. Portrety białostockich pisarzy, zespół redakcyjny: I. Czykwin, G. Legutko, W. Siniakowicz, W. Smaszcz, Białystok 1990, s. 5-6;12.

24 Майсей Сяднёў (1913-2001), эміграцыйны беларускі паэт і пісьменнік, які ад кастрычніка 1943-га года да мая 1944-га года знаходзіўся на Беласточчыне. Творца ва аўтабіяграфічным творы Беластоикі сшытак. Мая першая прапіска на Захадзе, напісаным у 1991 годзе, а выдадзеным у Мінску ў 2004 ў зборніку Масеева кніга. Успаміны, старонкі дзённіка, эсэ, Мінск 1994, напісаў успаімны пра “беластоцкі перыяд" жыцця.

25 М. Сяднёў, Масеева кніга. Успаміны, старонкі дзённіка, эсэ, Мінск 1994.

26 І. Гоўзіч, Лірыка-філасофская..., dz. суt., с. 296. 
пербалізаваную, плебейскую традыцыю, у якой аўтар не староніцца ад вульгарызмаў (Гіена, Сон, Жырафа) ці прадстаўляе “забаўныя” падзеі (Як Рыгор чорта выганяў, 3 апавяданняў старога сабакі Тарзана). Аднак яны не будуць у гэтым артыкуле прадметам аналізу, падобна, як тэксты, у якіх Геніюш з абагульненнем нейкіх з'яў і прадметаў выходзіць далёка ў экзатычнасць (Янычары, Чалма Умара Хаяма).

Памяць ${ }^{27}$ пакалення бацькоў Юркі Геніюша, звязана з жорсткай эпохай сталінскіх рэпрэсій, лагераў, з экстэрмінацыяй інтэлігенцыі, са спробай знішчэння “беларускага слова”. Геніюш, апынуўшыся ў Беластоку, магчыма пад уплывам беларускага нацыянальнага ўздыму ў Польшчы пасля 1956 года - відаць тое якраз па ягонай паэтычнай прозе - пачаў інтэнсіўна рэфлексіраваць над сваім лёсам. Лірычная проза аўтара Жменькі... - гэта вялікая настальгія па страчанай радзіме, на якую, аб чым дасканала ведаў, няма вяртання, а таксама па мове, слову.

Твор $A ф р ы л a^{28}$ гэта шэдэўр глыбокага філасофскага мыслення. Геніюш, уводзячы вобраз негра, жаліцца маці на боль, трагізм чалавечай экзістэнцыі ў непрыязным асяроддзі: “О-о-о! Чаму я чорны, чаму я чорны, мамо - хоць белы маю твар? [...] Хто чорны, той карак свой проціў волі гне” (125). Сімвалічны колер “чорны” кранаецца духоўнай прыгнечанасці.

Майстэрскі тэкст аб універсальна-інтэлектуальным характары $A \phi p b l-$ $\kappa a$ - так абагулены, так сімвалічна-алюзійны, што ён напісаўся ў Геніюша актуальным на ўсе часы і атрымаўся надзённым для кожнай сітуацыі. Зразумела, чорным чалавекам, у прамым сэнсе слова, сам ён не быў i таму не мог адлюстраваць нічога канкрэтнага, новага 3 псіхалагічна-

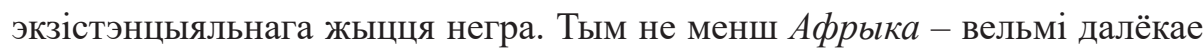

27 Разважанні адносна каштоўнасці індывідуальнай памяці кожнай асобы, якая з'яўляецца неадемнай часткай калектыўнай, сталі штуршком для разважанняў многіх даследчыкаў. Глядзі: J. Kleiner, Rola pamięci w recepcji dzieła literackiego $i$ w jego strukturze, [w:] tenże, Studia z zakresu teorii literatury, Lublin 1956; M. de Unamuno, O poczuciu tragiczności życia wśród ludzi i wśród narodów, przeł. H. Woźniakowski, Kraków-Wrocław 1984; M. Halbwachs, Społeczne ramy pamięci, Warszawa 2008; A. Assmann, Cztery formy pamięci, [w:] tejże, Między historia a pamięcią. Antologia, Warszawa 2013 і іншыя.

28 Ю. Геніюш, Афрыка [w:] Таго ж, Смыком па сэризы, Беласток 2013, с. 125. Далей пры спасылцы на гэта выданне ў дужках падаецца старонка. 
рэха той драмы, якая сталася з ягонымі бацькамі і, вядома, з ім - у СССР, затым Чэхаславакіі. Геніюш глядзіць на сямейную трагедыю праз прызму вострага расавага падзелу паміж людзьмі (пры тым, ён у ніякія палітычныя тэмы не ўваходзіў з увагі на горкі жыццёвы вопыт).

Несумненна $A ф p ы к а$ не датычыцца ягонай сітуацыі ў Польшчы: аўтар не мог і не меў падстаў змагацца $з$ польскімі ўладамі - у Польшчы атрымаў вышэйшую медычную адукацыю, працаваў, меў кватэру, сям’ю. Зразумела, Геніюшу вядомыя былі адчуванні калегаў-беларусаў Польшчы: „Dość podejrzenia u nas o białoruskość, by mieć zatrzaśnięte drzwi przed nosem w naszym urzędniczym Białymstoku”29. Тым не менш, нельга ставіць знаку роўнасці паміж сітуацыяй “белавежцаў” у Польшчы а інтэлігенцыі на Савецкай Беларусі.

Ян Чыквін адзначае, што калі толькі: “размова скіроўвалася ў той бок, Юрка звычайна засланяўся анекдотамі аб дзеўках, жартамі з вясковага жыцця-быцця, плебейскім гумарам альбо забаўляў слухача падгудкамі аб беларускай літаратуры"з0. Траўма перажытага ў дзіцячых гадах, сіроцтва - назаўсёды пакінула след у псіхіцы мастака. Стрыманыя паводзіны Геніюша, нават сярод сваіх беларускіх сяброў, пацвярджаюць, што ён не прабаваў у творчасці палемізаваць з кім-небудзь 3 палякаў ці беларусаў. Яму балела моцна сваё. Геніюш калі спрачаецца, то са сваімі людзьмі, беларусамі Беласточчыны - ускосна хоча ім напомніць, перасцерагчы іх перад лёгкай згубай свайго.

Ірына Гоўзіч таксама заўважае, што твор Афрыка сваім драматызмам набліжаецца да прытчаў Лявоніус Задумекус і Скарбы жыциця Максіма Гарэцкага, класіка беларускай літаратуры, у якіх “назіраецца такое ж крытычнае стаўленне да эксперыментаў, што праводзіліся над чалавечым жыццём у савецкі сталінскі час"з1.

Геніюш найперш піша для выратавання самога сябе, хоць, надрукаванае ў “Ніве”, яно ўскосна было вельмі павучальным і для беларусаў Польшы. Здаецца, што на той час для польскіх беларусаў “карані” твораў сына

29 S. Janowicz, Nasze tysiac lat. Z Sokratem Janowiczem rozmawia Jerzy Chmielewski, Białystok 2000, s. 140.

30 Я. Чыквін, Партрэт з памяиі, [w:] Таго ж, Далёкія і блізкія..., dz. суt., с. 118.

31 І. Гоўзіч, Лірыка-філасофская....., dz. суt., с. 297. 
Лаырсы Геніюш часта былі схаваныя, непрыкметныя, нябачныя, таму і ім здавалася, што піша адзін з іх, “тутэйшы”. Аднак, факт, што ён узрастаў у чэшскай Празе, шматнацыянальным асяроддзі - хадзіў да чэшскай школы, а затым рускай, вывучаў яшчэ англійскую мову, дома размаўлялася па-беларуску, а адначасова не было праблемаў з пераходам на іншыя мовы - то на Белсточчыну Геніюш прыехаў як чалавек з акрэсленай тоеснасцю і светапоглядам.

У Жменьцы... знайшлося некалькі твораў, якія сваімі адметнасцямі ўпісваюцца ў жанр прытчы з моцным эталагічным пафасам. Першым тэкстам раздзелу з'яўляецца менавіта твор біблейнага характару Спачатку было слова... (87). Ужо ў самім яго загалоўку Геніюш папярэджвае перад Страшным судом, на якім здраднікаў матчынай мовы чакае суровы прысуд: “Прад ім трапячыце. У ім Ваша смерць, нягоднікі ды злыдні. [...] Ратунку Вам не будзе, як няма спакою. [...] Бойцеся Слова!” (87). Не выклікае сумненняў, што слоў, выказаных у абарону роднага, немагчыма скарыць: “Не закаваць у путы жаўранка ў небе. Спрабуйце перад строем мару расстраляць” (87).

Развіццё матыву пакарання на Вечным судзе за уччынкі, словы, за "закапанне” сваіх талентаў у зямлю, іх “растрату”, заўважаецца і ў Запавеце. Аўтар нагадвае, што родная мова гэта тая ж з: “якою з светам развітацца найлягчэй” (124). Ён усведамляе сваю адказнасць перад нежывымі ўжо бацькамі за вернасць роднай мове: “Мая віна. Мая віна прад вамі. Бо вас няма, а словы мусяць жыць, мовы, якой мяне на гэты свет віталі” (124). Геніюш разумеў складанасць драматычных сцежак лёсу Беларусі, таму і ён папярэджвае будучыя пакаленні, што не можа быць літасці для тых, якія не ўшаноўваюць родных каштоўнасцей. “Бо ёсць грахі, якіх не выбачаюць” (124). Народ, які адрачэцца ад сваёй мовы, гісторыі, памяці продкаў, можа загінуць.

Яркі прыклад вернасці свайму роднаму, бацькоўскаму Геніюш падае і ў творы Сейбіт. Герой не хоча чужога багацця, бо ведае, што, беручы чужое, трэба будзе забыцца аб сваім скарбе, пакінуць яго на знішчэнне. Неспакой мастака слова наконт дэградацы беларушчыны, драматызму беларускага слова адносіцца не толькі да беларусаў метрапольных, але і да Беласточчыны.

Значэнне роднай мовы закранута і ў тэксце Вярніце Януку голас, у якім пісьменнік выкладае кранальную гісторыю страты голасу малым хлопчыкам. Вяртанню нямому голасу дапамагло шчырае пакаянне 
і ўсведамленне ім сваёй неправаты мыслення наконт матчынага слова. Яно набывае тут аздараўляльную і ачышчальную функцыю.

Роднае слова становіцца асноўнай дамінантай творчасці Геніюша, які ўпэўнены ў тым, што калі яно “замоўкне”, то “разбурыцца сістэма спрадвечных каштоўнасцей"з2. Паэтычны твор Hac мільёнь з'яўляецца прытчай пра сілу чалавечай салідарнасці. Лічыцца важнай кожная асоба ў змаганні за роднае (131). Тое, што не пад сілу аднаму чалавеку, адольваецца грамадою.

Носьбітам народнай мудрасці, пераказчыкам яе каштоўнасцей, 3'яўляецца дзядуля з твора Геніюша Век жыві - век вучыся. Ён, выпраўляючы ўнука на вучобу, наказвае яму, што ніколі нельга саромецца роднай мовы: “А то мужыцкая, а то халопская нават, кажуць, гаворка. А ты глядзі мне, не вер. Не так яно, браток, зусім не так, каб ведаў” (119).

У кароткім апавяданні Адкуль узяліся ў полі васількі падарожжа галоўнага героя Васілька, вымушана знешнімі абставінамі, адыгрывае важную ролю ў зразуменні каштоўнасці сваёй тоеснасці, пошуках свайго роднага дома, гэта значыць свайго “раю” на зямлі, у сэнсе як пераносным, так і літаральным. Тэкст, які спалучае рэальнае і нерэальнае, з'яўляецца прытчай аб тым, як шчырае пачуццё любові да роднага выратоўвае Васілька ад гібелі.

Любоў да роднай зямелькі, да бацькаўшчыны выяўлена і ў творы $3 a$ што кахаю? Чаму пра ияябе адно мару? Найхарашэйшая мая! Казачная! Адзіная.... Тут тэма вернасці роднай мове адлюстравана ў жыццёвым вопыце пажылога чалавека Рыгора, які шмат бачыў і перажыў, і рашуча пераконвае: “І паверце мне, старому, што калі наогул магчыма на гэтым свеце вечна кахаць каго, дык толькі адну яе, родную” (112).

Кранальным сумам па страчаным сваім і бацькоў лёсе насычаны тэкст Смыком па сэризь (130). Герой задумваецца: “Навошта ў чалавеку струны існуюць? Закрані абы-якую - гул ідзе”(130). Ліцэй з беларускай мовай навучання ў Бельску Падляшскім выклікае ў Геніюша амбівалентныя пачуцці. 3 аднаго боку, радасць за існаванне месца, дзе можна вывучаць беларускую мову, спрачацца пра беларускія кнігі. 3 другога боку, пісьменнік адчувае жаль, што: “Бо не ўдалося піць мне 3 тых крыніц, дзе кожны дзень купаллем іскрыцца, дзе летні вечар коласам шуміць, дзе

32 І. Гоўзіч, Лірыка-філасофская проза Юркі Геніюша, dz. суt., с. 296. 
ловіць прагна кожны гук, каб не забыцца - хто ты” (130). Аўтар выразна шкадуе свайго страчанага лёсу. Таму ён у творы Ліст-апавяданне да Biктара Шведа ставіць шэраг пытанняў сябру, каб глыбей зразумець прычыны яго пераезду ў Варшаву. Геніюш папярэджвае, што ў чужым культурова асяроддзі: “Захочаш іншым быць - наперад ніхто не пусціць, а чаго добрага, яшчэ па задзе накладуць” (114).

Усведамленне вечных ісцін, абарона свайго, роднага ўвыпукляецца і у Чорным па белым Геніюша. Спакуса пайсці і пагуляць па белых дарогах белага свету вялікая. "Вось толькі заімшэлыя, бацькоўскія, парогі кінуць - i ўжо яно. Самога Бога ты, здаецца, за бараду схапіў” (124). Аднак насалода ў чужым свеце імгненная. Новым чалавек хутка насычаецца. Усведамленне каштоўнасці роднага з'яўляецца выпадкова, калі лірычны герой убачыць: “Снежных юнацкіх мараў кужаль, не затоптаных, сонцам абмытых - скрутак застаўся недзе на гарышчы, у хаціне бацькавай пад шчытом"(125). Толькі вяртанне на "сваё месца" дапамагае ў маральным абнаўленні, духоўным самаачышчэнні з перажытага. Аўтар перасцерагае, што цана за захапленне чужым акажацца вялікай, пагражае стратай свайго незваротна: “І белы-белы матчын твар растае ў малочным тумане. Назаўсёды амаль. [...] вуснаў сухіх ужо не змочыць” (125).

Чорным па бельм Геніюша выклікае рэмінісцэнцыі 3 мініяцюрай Сыну Сакрата Яновіча, які сваіх герояў-адрачэнцаў ад роднага, шукаючых лёгкага жыцця ў горадзе называў “хамамі на паркеце”: “Рассохлы парог хаты бацькоў пакінуць, каб ад долі ўцячы - можаш. Туманны усход і пах ліпаў забыць, каб шумным асфальтам пакрочыць - можаш. [...] А калі слязьмі боль пакоціцца, калыханку матчыну ўспомні”"33.

Лірыка-філасофскія запісы Геніюша і Загоны Яновіча пісаліся і друкаваліся прыблізна ў той самы час. Яны шмат у чым набліжаны да сябе, ім уласцівы выхад 3 лакальнай глебы да абагульнення, супрацьстаянне чужой культуры, узвышэнне сваёй роднай, рэальныя і фантазійныя падзеі атрымоўваюць глыбокае філасофскае вымярэнне. Абодвум мастакам слова характэрна пісанне алюзіямі, намёкамі. Аднак, з увагі на лёс бацькоў і пражыванне ў дзяржаве, якая знаходзілася ў сферы савецкіх уплываў, Геніюш больш намякаў чым сябар, напрыклад у яго тэкстах адсутнічаюць

33 С. Яновіч, Сыну, [w:] Таго ж, Загоны, Беласток 1969, с. 15. 
тапанімічныя названні. У яго творчасці слова "роднае" адносіцца да беларускай культуры, матчынай мовы, яно не абазначае тое самае, што на англійскай мове „homeland”, значыць, “Радзіма”, Айчына, канкрэтная прастора. У Яновіча “роднае” гэта найперш Крынкі, “маленькая Айчына”.

Роднае ў Геніюша, як і ў Яновіча, неразлучна звязана з вобразам маці, вынесенага з часоў дзяцінства. У тэксце Дзіиячьля мары (128) выразна выяўлена настальгія Юркі па мінулым, найрадасным перыядзе жыцця.

Літаратуразнаўца Ян Чыквін наступнымі лапідарнымі штрыхамі, дакладна аддае сутнасць “партрэта” таленавітага “белавежца”:

[...] Юрка Геніюш выдзяляўся сваім інтэлігенцкім паходжаннем. Кідалася ў вочы найперш тое, што быў ён асобаю знешне вольнай. Начытанасць, валоданне замежнымі мовамі і пашана да сваёй роднай, рэдкая чысціня вымаўлення, нацыянальная годнасць, адкрытыя гарызонты поглядаў, жывое рэагаванне на атачэнне і грамадска-палітычныя з'явы, здаровая пераменлівасць паводзін былі яму натуральна ууласцівыя 34 .

Нечаканая, раптоўная смерць з'яўляецца вялікай стратай для беларускага асяроддзя: “Нам заўсёды будзе не хапаць менавіта ягонага апісання гэтай гісторыі (жыцця ў чэшскай Празе - дап. А.С.), праніклівага допісудапаўнення да Споведзі ${ }^{35}$ маці, Ларысы Геніюш"36.

Жменька слоў крылатых выразна сведчаць аб паэтычнай шчырасці, эмацыянальнай адкрытасці Юркі Геніюша. У ёй няма “наслаення” польскай культуры, якой, хай сабе падсвядома, надзелена творчасць польскіх беларусаў37. Геніюш не паэтызуе “чужой” святасці, а інтэнсіфікуе, заглыб-

34 Тамсама, c. 118.

35 Тамсама, с. 117.

36 Тамсама, c. 117

37 Беларускамоўныя творцы, па які бок мяжы яны ні знаходзіліся б, яднаюцца спецыфікай беларускага нацыянальнага пытання. Літаратары -“белавежцы” - прадстаўнікі беларускай меншасці ў Польшчы, існуюць у кантэксце польскіх сацыяльна-палітычных i эканамічных праблем і ў кантэксце польскай нацыянальнай культуры. I яны самі, i ix асяроддзе - крыніца тэм і вобразаў для творчасці, у штодзённым жыцці карыстаюцца польскай мовай, беларуская ж мова выступае мовай неіснуючай рэчаіснасці, рэчаіснасці, створанай аўтарскай фантазіяй. Г. Тычка, Літаратура Беласточчыны ў агульнанаизыянальным беларускім кантэксие, [w:] Той жа, Наџьыянальнае.... dz. суt., с. 26. 
ляецца ў сваю, беларускую, пры тым не ў сэнсе фальклору аб вясковым паходжанніi, а ўкаранёнай ў хрысціянскіх тэкстах, у еўрапейскай культуры. Бясспрэчна, што глыбокая арыгінальнасць паэта ўзбагачае наробак членаў БЛА “Белавежа” “карэнна-чыстай” беларускай творчасцю. Жывая беларуская мова, памяць аб культуры, традыцыі, тоеснасці, рэлігіі - вось асноўныя каштоўнасці роднай культуры мастака, якія ён у лірычнай прозе падымае да sacrum.

\section{Литература}

M. Bachtin, Koncepcja nauki o literaturze, [w:] Bachtin: dialog - język - literatura, pod red. E. Czaplejewicza i E. Kasperskiego, Warszawa 1983.

Бічэль Д., Сям'я Геніюшаў - Ларыса і Янка, іх сын Юрка, [w:] Данута Бічэль, Выбраныя творы, Мінск 2016.

Геніюш Л., Споведзь, [w:] Тая ж, Выбраныя творы, Мінск 2000.

Геніюш Ю., Смыком па сэрцы, Беласток 2013.

Гоўзіч І., Лірыка-філасофская проза Юркі Геніюша, “Тэрмапілы” 2008, № 12.

Яновіч С., Сыну, [w:] Tago ž, Zagony, Belastok 1969.

Яновіч С., Прадмова, [w:] Маці і сын, Ларыса Геніюш: Сэрца, Юрка Геніюш: Да свету, Беласток 1992.

Janowicz S., Nasze tysiąc lat. Z Sokratem Janowiczem rozmawia Jerzy Chmielewski, Białystok 2000.

Leończuk J., Wersy poetyckie Jerzego Geniusza, [w:] Ю. Геніюш, Смыком па сэрцы, Беласток 2013.

Лукша М., Ой, мама, чаму я чорны..., [w:] Ю. Геніюш, Смыком па сэрцы, БеласTOK 2013.

Orłowski A., Fascynacje pograniczem w dwudziestowiecznej myśli filozoficznej $i$ antropologicznej - Bachtin, Todorov, Buber, Lèvinas, „Pogranicze. Polish Borderlands Studies", t. 4, nr 1, s. 10.

Сяднёў М., Масеева кніга. Успаміны, старонкі дзённіка, эсэ, Мінск 1994.

Тычка Г., Аўтарская канцэпцыя чалавека і свету ў мініяцюрах Сакрата Яновіча іяна Чыквіна, [w:]Той жа, Нацыянальнае. Індывідуальнае. Агульначалавечае, Беласток 2015. 
Чыквін Я., Партрэт з памяці, [w:] Таго ж, Далёкія іблізкія. Беларускія пісьменнікі замежжа, Беласток 1997.

\section{Bibliografia}

Bachtin M., Koncepcja nauki o literaturze, [w:] Bachtin: dialog - język - literatura, pod red. E. Czaplejewicza i E. Kasperskiego, Warszawa 1983.

Bìčèl' D., Sâm 'â Genîǔšaǔ - Larysa ì Ânka, ì syn Ûrka, [w:] Danuta Bìčèl', Vybranyâ tvory, Mìnsk 2016.

Geniûš L., Spovedz', [w:] Taâ ž, Vybranyâ tvory, Mìnsk 2000.

Geniûš Û., Smykom pasèrcy, Belastok 2013.

Goǔzič ì., Lìryka-filasofskaâ proza Ûrkì Genîuša, “Tèrmapìly” 2008, № 12.

Яновіч С., Сыну, [w:] Таго ж, Загоны, Беласток 1969

Ânovič S., Pradmova, [w:] Macì ì syn, Larysa Genîǔs: Sèrca, Ûrka Geniûš: Da svetu, Belastok 1992.

Janowicz S., Nasze tysiąc lat. Z Sokratem Janowiczem rozmawia Jerzy Chmielewski, Białystok 2000.

Leończuk J., Wersy poetyckie Jerzego Geniusza, [w:] Genîǔš Û., Smykom pa sèrcy, Belastok 2013.

Lukša M., Oj, mama, čamu â čorny..., [w:] Geniûš Û., Smykom pa sèrcy, Belastok 2013.

Macì ì syn, Larysa Genìuš: Sèrca, Ûrka Geniûš: Da svetu, Belastok 1992.

Orłowski A., Fascynacje pograniczem w dwudziestowiecznej myśli filozoficznej $i$ antropologicznej - Bachtin, Todorov, Buber, Lèvinas, „Pogranicze. Polish Borderlands Studies", t. 4, nr 1, s. 10.

Sâdnëǔ M., Maseeva knìga. Uspamìny, staronkì dzënnìka, èsè, Mìnsk 1994.

Tyčka G., Aǔtarskaâ kancèpcyâ čalaveka ì svetu ǔ mìniâcûrah Sakrata Ânoviča ì Âna Čykvìna, [w:] Toj ža, Nacyânal'nae. İndyvìdual'nae. Agul'načalavečae, Belastok 2015.

Čykvìn Â., Partrèt z pamâcì, [w:] Tago ž, Dalëkiâ ì blìzkiâ. Belaruskiâ pis'mennìkì zamežža, Belastok 1977. 